\title{
Treatment of Spontaneous Intracranial Hypotension with Intravenous Factor XIII Administration: Initial Clinical Experience
}

\author{
Spontan Intrakraniyal Hipotansiyonun Intravenöz Faktör XIII \\ Uygulanmasıyla Tedavisi: Başlanguç Klinik Deneyim
}

Kimihiro NAGATANI, Satoru TAKEUCHI, Kojiro WADA, Kentaro MORI, Katsuji SHIMA

National Defense Medical College, Department of Neurosurgery, Tokorozawa, Japan

Corresponding Author: Kimihiro NAGATANI / E-mail: naval.kimi@gmail.com

\begin{abstract}
AIM: Coagulation Factor XIII plays an important role in wound healing by stabilizing the fibrin clot. We hypothesized that Factor XIII administration might promote the repair of cerebrospinal fluid leak sites and lead to resolution of the orthostatic headache in patients with spontaneous intracranial hypotension (SIH). The aim of this study was to investigate the efficacy of intravenous Factor XIII administration in SIH patients.

MATERIAL and METHODS: A retrospective review of nine patients (four men, five women; mean age $42.3 \mathrm{yr}$ ) with SIH resistant to conservative treatment (bed rest, hydration and analgesics) was performed. All patients had an orthostatic headache. Intravenous administration of Factor XIII (1200 units per day for at least five days) was additionally performed on all patients.

RESULTS: The orthostatic headache completely resolved and never reoccurred in six patients (67\%), and partially resolved in two patients (22\%). One patient $(11 \%)$ had no change in headache activity. No complications occurred in any patients treated with Factor XIII.

CONCLUSION: This study may suggest that intravenous administration of Factor XIII is useful for treating SIH, even if the patients are resistant to conservative treatment.
\end{abstract}

KEYWORDS: Spontaneous intracranial hypotension, Factor XIII, Orthostatic headache, Conservative treatment, Epidural blood patch

öz

AMAÇ: Koagülasyon Faktörü XIII, fibrin pıhtısının stabilizasyonu yoluyla yara iyileşmesinde önemli bir rol oynar. Faktör XIII uygulanmasının serebrospinal sıvı sızıntı bölgelerinin onarımını destekleyeceği ve spontan intrakraniyal hipotansiyon (SiH) durumunda ortostatik baş ağrısının geçmesini sağlayacağını düşündük. Bu çalışmanın amacı, SiH hastalarında intravenöz Faktör XIII uygulanmasının etkinliğini araştırmaktı.

YÖNTEM ve GEREÇLER: Konservatif tedaviye (yatak istirahati, hidrasyon ve analjezikler) dirençli dokuz SiH hastasının (dört erkek, beş kadın, ortalama yaş 42,3 yıl) retrospektif bir değerlendirmesi yapıldı. Tüm hastalarda ortostatik baş ağrısı vardı. Tüm hastalara intravenöz olarak Faktör XIII uygulanmıştı (en az beş gün boyunca günde 1200 ünite).

BULGULAR: Ortostatik baş ağrısı altı hastada (\%67) tamamen geçip tekrar oluşmadı ve iki hastada (\%22) kısmen geçti. Bir hastada (\%11) baş ağrısında bir değişiklik olmadı. Faktör XIII ile tedavi edilen hiçbir hastada bir komplikasyon oluşmadı.

SONUÇ: Çalışma konservatif tedaviye dirençli hastalarda bile SiH tedavisinde intravenöz Faktör XIII uygulanmasının faydalı olduğunu düşündürmektedir.

ANAHTAR SÖZCÜKLER: Spontan intrakraniyal hipotansiyon, Faktör XIII, Ortostatik baş ağrısı, Konservatif tedavi, Epidural kan yaması

\section{INTRODUCTION}

Spontaneous intracranial hypotension $(\mathrm{SIH})$ is caused by spontaneous spinal cerebrospinal fluid (CSF) leaks and is known for causing orthostatic headaches (11). Spontaneous spinal CSF leaks occur at the spinal level, particularly the thoracic spine or cervicothoracic junction $(9,11)$. Treatment ranges from conservative management, such as bed rest, hydration and analgesics, to invasive procedures, such as the autologous epidural blood patch (EBP) or surgical closure $(9,11)$. Among these treatment options, EBP is considered the treatment of choice for those patients who have failed the initial conservative treatment (2). However, there is a possibility of side effects and complications including back pain, radiculopathy, meningitis, and rebound intracranial hypertension (9).

Coagulation factor XIII is well known as a clot-stabilizing factor and circulates in the blood in the form of a proenzyme $(4,10)$. Thrombin and $\mathrm{Ca}^{2+}$ convert Factor XIII to its active form. Factor XIII stabilizes fibrin and protects it against fibrinolysis by mechanically cross-linking fibrin chains and the alpha- 2 
plasmin inhibitor at the end of the clotting cascade. This fibrinstabilizing function within the coagulation cascade has been well investigated. Additionally, Factor XIII is involved in wound healing by encouraging the migration and proliferation of fibroblasts into the clot (1). Several investigators have reported that administration of Factor XIII accelerates wound healing in patients with suture dehiscences, fistulae and CSF leak after skull base surgery $(6,8)$. Therefore, we hypothesized that Factor XIII administration might promote the repair of CSF leak sites and lead to resolution of the orthostatic headache in $\mathrm{SIH}$ patients, without performing invasive procedures such as EBP. We previously reported cases of two patients with $\mathrm{SIH}$ that was successfully treated by intravenous Factor XIII administration (5). We herein describe a series of nine additional patients with $\mathrm{SIH}$ that was resistant to traditional conservative treatment and successfully treated with Factor XIII administration.

\section{PATIENTS and METHODS}

This study was approved by the Clinical Research Ethics Committee of the National Defense Medical College. Between January 1998 and December 2012, we treated 11 consecutive patients diagnosed with $\mathrm{SIH}$ according to the International Classification of Headache Disorders criteria for headaches attributed to spontaneous (or idiopathic) low CSF pressure (3). Among the patients, two that were reported in a previous study (5) were excluded in this study. All patients had a postural headache, which was alleviated to a variable extent on recumbency. For the initial treatment, traditional conservative treatment (bed rest, analgesics and intravenous fluid replacement) was tried in all patients. According to the patients' subjective responses, we defined a failure of conservative treatment as a lack of response for over a week after the initial treatment or deterioration after the initial treatment. When these methods failed, intravenous administration of a purified pasteurized Factor XIII concentrate (Fibrogammin P, CSL Behring, Japan: 1200 units per day) was additionally performed for at least $5 \mathrm{~d}$ (the maximum duration: $10 \mathrm{~d}$ ). Serum Factor XIII activity was measured before treatment with Factor XIII and $1 \mathrm{~d}$ after the end of treatment with Factor XIII. Serum Factor XIII activity was analyzed using a commercial determination system for automatic Factor XIII analysis (Berichrom Factor XIII, SIEMENS, Germany). The efficacy of treatment was assessed according to the patients' subjective responses at the time of discharge as complete resolution of headache, partial resolution, no response or deterioration.

\section{RESULTS}

Nine patients (four men, five women; mean age $42.3 \mathrm{yr}$ ) were included in this study (Table I). All patients had orthostatic headache. Other manifestations were neck stiffness, tinnitus and nausea. Hypacusia and photophobia were not seen in any patients. Spinal taps had been performed in six patients. Three patients showed low CSF opening pressure $(<60 \mathrm{~mm}$ $\mathrm{H}_{2} \mathrm{O}$ ), whereas three patients showed CSF opening pressure $\geq 60 \mathrm{~mm} \mathrm{H}_{2} \mathrm{O}(70,130$, and $150 \mathrm{~mm} \mathrm{H} 2 \mathrm{O}$, respectively). Three patients did not undergo CSF examination. Brain magnetic resonance imaging (MRI) was performed in all patients at the initial diagnosis. Diffuse pachymeningeal gadolinium enhancement was present in five patients. Spinal MRI was performed on five patients, MR myelography on eight, and radioisotope cisternography on seven. CT myelography was not performed on any patients. Spinal MRI or MR myelography or radioisotope cisternography showed the CSF leakage site in six of nine patients. The locations of CSF leakage were as follows: cervical, one patient; cervicothoracic, three; mid-lower thoracic, zero; lumbar, two; and unknown, three. Median value of serum Factor XIII activity (normal range $70 \%-140 \%$ ) before the treatment with Factor XIII was $89 \%$ (range 62\%-138\%), and median value of post-treatment with Factor XIII was 156\% (range 109\%-282\%). All patients failed to recover during an initial period of traditional conservative treatment (bed rest, hydration and analgesics). After the initiation of conservative treatment, two patients showed severely deteriorated headache activity (Day 2 and Day 5, respectively). Seven patients had no change, even though they underwent conservative treatment for over a week (from 7 to $35 \mathrm{~d}$; mean $11.8 \mathrm{~d}$ ). Therefore, intravenous administration of Factor XIII (1200 units per day) was additionally performed on all patients. The total duration of intravenous Factor XIII administration ranged from 5 to $10 \mathrm{~d}$ (mean $6.25 \mathrm{~d}$ ). The total duration of medication (conservative treatment with additional administration of Factor XIII) ranged from 7 to 40 $\mathrm{d}$ (mean $17.7 \mathrm{~d}$ ). Overall, the orthostatic headache completely resolved in six patients (67\%), and partially in two patients (22\%). One patient (11\%) had no change in headache activity. No complication occurred in any patients treated with Factor XIII.

\section{DISCUSSION}

Bed rest has traditionally been advocated as the first-line treatment of $\mathrm{SIH}$, together with hydration and/or analgesics, but the real therapeutic efficacy of such treatment has still not been established $(2,9)$. This study revealed that treatment with additional intravenous administration of Factor XIII successfully improved the orthostatic headache in eight out of nine patients (89\%) who were resistant to conservative therapy. This is the largest case series of patients with $\mathrm{SIH}$ successfully treated with Factor XIII administration.

$\mathrm{SIH}$ is traditionally attributed to spontaneous spinal CSF leaks $(11,12)$. The precise cause of the spontaneous spinal CSF leaks remains unknown, but underlying fragility of the spinal meninges is generally suspected (12). The dural weakness predisposes to the formation of dural defects that allow CSF to leak into the epidural space (11). Coagulation Factor XIII is a transglutaminase that is the last step in the coagulation cascade, and it plays an important role in wound healing by stabilizing the fibrin clot $(1,4,10)$. There are several reports that administration of Factor XIII accelerates wound healing in patients with suture dehiscences, fistulae and CSF leak after skull base surgery $(6,8)$. As for $\mathrm{SIH}$, there is only one case report in which two patients with SIH were successfully 
Table I: Clinical Data in Patients with Spontaneous Intracranial Hypotension

\begin{tabular}{|c|c|}
\hline Patient no. & 9 \\
\hline Age at diagnosis, years (range) & $42.3(20-61)$ \\
\hline Male/female ratio & $4 / 5$ \\
\hline \multicolumn{2}{|l|}{ Symptoms } \\
\hline Orthostatic headache & 9 \\
\hline Neck stiffness & 2 \\
\hline Tinnitus & 2 \\
\hline Hypacusia & 0 \\
\hline Photophobia & 0 \\
\hline Nausea & 5 \\
\hline \multicolumn{2}{|l|}{ CSF Opening pressure $\left(\mathrm{mmH}_{2} \mathrm{O}\right)$} \\
\hline$<60$ & 3 \\
\hline$\geq 60$ & 3 \\
\hline Not examined & 3 \\
\hline \multicolumn{2}{|l|}{ Diagnostic studies } \\
\hline Brain MRI & 9 \\
\hline Spine MRI & 5 \\
\hline Radioisotope cisternography & 7 \\
\hline CT myelography & 0 \\
\hline MR myelography & 8 \\
\hline \multicolumn{2}{|l|}{ CSF leakage site } \\
\hline Cervical & 1 \\
\hline Cervico-thoracic & 3 \\
\hline Mid-lower thoracic & 0 \\
\hline Lumber & 2 \\
\hline Unknown & 3 \\
\hline DPGE (+) & 5 \\
\hline \multicolumn{2}{|l|}{ Serum Factor XIII activity (\%) } \\
\hline Pretreatment, median (range) & $89(62-138)$ \\
\hline Posttreatment, median (range) & $156(109-282)$ \\
\hline \multicolumn{2}{|l|}{ Duration of treatment with Factor XIII } \\
\hline $\begin{array}{l}\text { Duration of medication } \\
\text { mean, } d \text { (range) }\end{array}$ & $17.7(7-40)$ \\
\hline \multicolumn{2}{|c|}{ Outcome of patients treated with Factor XIII administration on discharge } \\
\hline CR & 6 \\
\hline PR & 2 \\
\hline $\mathrm{NC}$ & 1 \\
\hline $\mathrm{D}$ & 0 \\
\hline
\end{tabular}

CR: complete resolution of headache; PR: partial resolution of headache; NC: no change of headache; D: deterioration of headache; CSF: cerebrospinal fluid; DPGE: diffuse pachymeningeal gadolinium enhancement detected by cranial MRI. 
treated by intravenous Factor XIII administration (5). In this study, the median value of Factor XIII activity before the treatment with Factor XIII was $89 \%$, within the normal range (70\%-140\%). However, the median value of post-treatment Factor XIII activity was 156\%, greatly increased beyond the normal range. It has been reported that large amounts of Factor XIII are capable of improving the wound granulation (7). Moreover, the activity of serum Factor XIII shows positive correlation with the promotion of wound healing. Mishima et al. (8) reported that the efficacy of Factor XIII concentrate in the improvement of postoperative wound healing disorders was examined in 61 patients, and that both Factor XIII activity and its rate of increase before and after treatment were important in wound healing. Based on these reports, we consider that higher activity of serum Factor XIII might promote the repair of CSF leak sites and lead to resolution of the orthostatic headache of $\mathrm{SIH}$ in this study.

If conservative treatment fails, the treatment of choice is an $\operatorname{EBP}(2,9)$. However, there are potential complications of EBP including transient back pain (35\%-100\% incidence), radiculopathy, meningitis, and rebound intracranial hypertension (3). On the other hand, a purified pasteurized Factor XIII concentrate, derived from human plasma, is safely available for patients with decreased Factor XIII activity to potentially support and promote wound healing. In this study, no complications occurred in any patients treated with Factor XIII. Therefore, we consider that intravenous administration of Factor XIII is a less invasive treatment, and that intravenous administration of Factor XIII can be an acceptable option before consideration of EBP, if traditional conservative treatment is ineffective. We also consider that it might be better to perform conservative treatment with Factor XIII administration as a first-line treatment of SIH.

We are aware that the number of cases enrolled was too small to draw definite conclusions about the efficacy of intravenous administration of Factor XIII and that we did not perform the treatment with intravenous administration of Factor XIII alone in this study. In addition, the duration of conservative treatment was relatively short in this study, and we could not determine whether time might play an additional role in improving patients' headache. A prospective randomized study is warranted before making conclusions about the efficacy. Nevertheless, we consider the proposed treatment a safe method that should be considered before attempting the more invasive EBP. In conclusion, we believe that intravenous administration of Factor XIII is useful for treating $\mathrm{SIH}$, even if the patients are resistant to conservative treatment.

\section{REFERENCES}

1. Brown LF, Lanir N, McDonagh J, et al: Fibroblast migration in fibrin gel matrices. Am J Pathol 142: 273-283, 1993

2. Franzini A, Messina G, Nazzi V, et al: Spontaneous intracranial hypotension syndrome: $A$ novel speculative physiopathological hypothesis and a novel patch method in a series of 28 consecutive patients. J Neurosurg 112: 300-306, 2010

3. Headache Classification Subcommittee of the International Headache Society: The International Classification of Headache Disorders, 2nd edn. Cephalalgia 24 Suppl 1: 79-80, 2004

4. Ichinose A: Physiopathology and regulation of factor XIII. Thromb Haemost 86: 57-65, 2001

5. Ishihara S, Fukui $\mathrm{S}$, Otani $\mathrm{N}$, et al: Evaluation of spontaneous intracranial hypotension: Assessment on ICP monitoring and radiological imaging. Br J Neurosurg 15: 239-241, 2001

6. Kawamura A, Tamaki N, Yonezawa K, Nakamura M, Asada M: Effect of factor XIII on intractable CSF leakage after a transpetrosal-approach operation: A case report. No Shinkei Geka 25: 53-56, 1997

7. Marktl W, Rudas B: The effect of factor XIII on wound granulation in the rat. Thromb Diath Haemorrh 32: 578-581, 1974

8. Mishima Y, Nagao F, Ishibiki K, Matsuda M, Nakamura N: Factor XIII in the treatment of postoperative refractory woundhealing disorders. Results of a controlled study. Chirurg 55: 803-808, 1984

9. Rahman M, Bidari SS, Quisling RG, Friedman WA: Spontaneous intracranial hypotension: Dilemmas in diagnosis. Neurosurgery 69: 4-14, 2011

10. Richardson VR, Cordell P, Standeven KF, Carter AM: Substrates of Factor XIII-A: Roles in thrombosis and wound healing. Clin Sci (Lond) 124: 123-137, 2013

11. Schievink WI: Spontaneous spinal cerebrospinal fluid leaks and intracranial hypotension. JAMA 295: 2286-2296, 2006

12. Schievink WI, Meyer FB, Atkinson JL, Mokri B: Spontaneous spinal cerebrospinal fluid leaks and intracranial hypotension. J Neurosurg 84: 598-605, 1996 